Article

\title{
Analysis of Biodeteriogens on Architectural Heritage. An Approach of Applied Botany on a Gothic Building in Southern Italy
}

\author{
Maria Emanuela Mascaro, Giuseppe Pellegrino and Anna Maria Palermo *(D) \\ Department of Biology, Ecology and Earth Sciences, University of Calabria, 87036 Rende, Italy; \\ mariaemanuelamascaro@gmail.com (M.E.M.); giuseppe.pellegrino@unical.it (G.P.) \\ * Correspondence: anna_maria.palermo@unical.it; Tel.: +39-984-492956
}

Citation: Mascaro, M.E.; Pellegrino,

G.; Palermo, A.M. Analysis of

Biodeteriogens on Architectural

Heritage. An Approach of Applied

Botany on a Gothic Building in

Southern Italy. Sustainability 2022, 14,

34. https://doi.org/10.3390/

su14010034

Academic Editors: Flavia Bartoli,

Seyedh Zohreh Hosseini,

Emanuela Cicinelli and

Andrea Pezzuolo

Received: 2 November 2021

Accepted: 14 December 2021

Published: 21 December 2021

Publisher's Note: MDPI stays neutral with regard to jurisdictional claims in published maps and institutional affiliations.

Copyright: () 2021 by the authors. Licensee MDPI, Basel, Switzerland. This article is an open access article distributed under the terms and conditions of the Creative Commons Attribution (CC BY) license (https:// creativecommons.org/licenses/by/ $4.0 /)$.

\begin{abstract}
The degradation of stone materials depends on several interlinked factors. The effects caused by biodeteriogens on mineral-based substrates are now increasingly considered in the field of cultural heritage conservation from different experimental approaches. In this study, biodeteriogenic micro- and macroflora within the gothic building of Santa Maria della Pietà, Squillace, Calabria, have been analyzed using multiple approaches, such as optical microscopy and molecular techniques. All 17 plant species detected are usually widespread in Mediterranean regions and some of these, such as Ailanthus altissima and Ficus carica, showed a very high hazard index, which is potentially dangerous for masonry stability. Fungi, cyanobacteria, and green algae were identified within biofilm compositions in a total of 23 different taxa, showing many similarities with microbial associations commonly found in cave and hypogean environments. All of the 11 fungal taxa detected belong to Ascomycota phylum, with Penicillium as the most represented genus. Photoautotrophic organisms are mostly represented by filamentous genera, with widespread presence of Leptolyngbya as the most abundant genus. The results highlighted how the singular environmental conditions of the study site, combined with the architectural features and the building materials, determined all the degradation phenomena affecting the building's internal surfaces, compromising over time the structural integrity.
\end{abstract}

Keywords: architectural heritage; biodeterioration; cultural heritage conservation; stone colonization; biofilm; cyanobacteria; fungi; green algae; vascular plants

\section{Introduction}

Historic buildings, like all materials exposed to the external environment, are interconnected with surrounding abiotic and biotic factors. Therefore, they can be considered as real ecosystems where complex interactions develop between the biocenosis, the substrate, and the physical and edaphic factors of the geographical environment [1]. Over time, all stone materials succumb to spontaneous decay processes due to their intrinsic characteristics, such as the mineralogical composition of the rocks, joined with the extrinsic effects of climatic agents [2,3]. Subjected to environmental conditions, stone materials undergo physical and chemical alterations occurring in the form of deterioration phenomena, such as cracks, erosion, abrasion, and detachment, which may promote biological colonization [4]. Biological contamination to stone surfaces is considered one of the main causes of deterioration processes, not only as aesthetic damage but also as a degradation factor that could irreversibly alter stone materials, contributing to rock modification $[5,6]$. Biodeterioration, defined as "any undesirable change in a material brought about by the vital activities of organisms" [7], is a secondary phenomenon that frequently occurs on pre-deteriorated stone surfaces [8]. It also depends on the susceptibility of the stone materials to being colonized, i.e., its bioreceptivity [9-11]. However, it is often difficult to attribute which damages are directly related to the actions of biodeteriogens [12,13]. In relation to the ecological and climatic characteristics of the various geographical contexts, 
it is possible to distinguish different types of environments which play a decisive role in the development of specific biological agents [14]. In this sense, the concept of biodeterioration ecology proposed by Caneva and Ceschin [15] highlights the close relationship between the organisms colonizing stone materials and the complex of the environmental factors that regulate their growth. For an effective diagnostic approach for cultural heritage buildings, in addition to having knowledge of the characteristics of the stone materials, the study of plant biology is extremely important for an investigation of the potential effects of biological agents, as well as for understanding the relevance of its ecological and environmental context. The stones of historical buildings are the ideal mineral-based substrates for the growth and proliferation of a wide variety of microorganisms such as bacteria, fungi, algae, cyanobacteria, as well as mosses and lichens [16]. These microorganisms can grow in communities known as biofilms. Biofilms are mono- or multilayered complex cell systems of one or more species of microorganisms, which can grow attached to any solid substrate surrounded by a self-produced exopolysaccharides matrix (EPS) $[17,18]$ in which phototrophic and heterotrophic organisms are embedded. This mucous matrix allows the cohesion of biofilm and its adhesion to a surface; regulates the interactions between microorganisms, the surrounding environment, and the substrate; mediates intracellular communications; and protects microorganisms against desiccation and toxic agents [19-21]. The composition of biofilm microbiota can develop in various ways depending on the surrounding environment's ecology and microbial biodiversity, the climate conditions, the substrate physicochemical properties, and nutrient availability [22,23]. The color of these biological formations directly depends on their growth level, thickness, and type of biocenosis [1,4]. In particular, environments with dim natural light and high humidity rates are often affected by phototrophic subaerial biofilm colonization [18]. The presence of epilithic organisms [24], commonly cyanobacteria and green algae, causes variation in stone color, altering the aesthetic of the surface's features $[25,26]$. Over time, the accumulation of photosynthetic biomass allows the penetration of biofilm microbes into the cracks and pores of stone materials, promoting the activity of endolithic microbial communities which potentially contribute to the physical and chemical breakdown of the stone material [27]. Furthermore, vascular plants are also able to colonize stone materials when they encounter favorable environmental conditions. The ability of ruderal flora to contribute to the deterioration of building materials also plays an important role, potentially causing mechanical and chemical damages to wall structures [12] depending on their life form and the shape and extension of their roots system [28]. In this study, the micro- and macroflora present on the structure of a Gothic building in southern Italy, known as Santa Maria della Pietà, have been analyzed through combining optical microscopy, microbial culture methods, molecular techniques (i.e., DNA isolation and PCR amplification), and floristic surveys. The objective was to identify and classify the species biodiversity of microbial communities and higher plants, considering their potential degrading actions on the monument.

\section{Materials and Methods}

\subsection{Study Site Environment and State of the Art}

Santa Maria della Pietà (SMP) dates back to the XIII century, although there is no certain information on the intended use of the building at the time of its construction. It is thought that this is what is left of a civil-military "domus scolaciorum" [29], which was later adapted to a place of religious worship. SMP is located on a narrow blind lane in the center of the old town of Squillace, Calabria, South Italy (lat: $38^{\circ} 46^{\prime} 54.8^{\prime \prime} \mathrm{N}$, lon: $16^{\circ} 31^{\prime} 14.5^{\prime \prime} \mathrm{E}$ ) (Figure 1a), which is one of the most culturally and historically representative examples of a Magna Graecia site and a rich urban center during the Norman period in the Calabrian region. Therefore, the historic center of Squillace is included among the most important sites for tourist itineraries in Calabria. It is located upon three hills which are around $344 \mathrm{~m}$ above the homonymous Gulf of the Ionian Sea, surrounded by streams and a countryside rich in olive groves and vegetative species typical of the Mediterranean scrub [30]. Squillace has a temperate and maritime climate typical of the Mediterranean, and is included in 
the Csa climate group according to the Köppen-Geiger classification [31]. However, long periods of intense humidity with frequent fog phenomena frequently occur. Far from main roads, SMP is protected from urban and anthropic pollution, is little exposed to winds, and fairly shielded from the sun by surrounding buildings (Figure 1b). The entire SMP building structure stands directly on sandstone and mainly consists of granitic rock. It consists of an almost-square plan with walls composed of irregular stone blocks held in place by mortar. The external façades are still partially covered by a single layer of aerial lime-based plaster with outcropping terracotta shards. The external west-facing wall has no openings and is completely occluded by an embankment that extends in height to the roof. The north and south (Figure 1c) façades are partially covered by rock-based embankments. On the east wall (Figure 1d), which is the only one entirely visible, there are four single-lancet open windows and a small door; the main entrance opens on the north façade (Figure 1e). The single internal room is divided into four spans with cross vaults supported by four semi-pillars, four corner columns and a large square central pillar (Figure 1f). A niche opens on the right side of the south wall, while a memorial gypsum plate is placed on the left. A gypsum rock-built altar table is located on the left side of the west wall. All of the architectural elements, such as the external corners, the ribs, the internal central pillar, the four semi-pillars and the corner columns, the portals, and the single-lancet windows' moldings, consist of evaporitic limestone. All of the plaster on the internal walls consists of a multi-layer composition, formed by an aerial lime mortar bottom layer with quartz, feldspar, biotite, and fragments of magmatic and metamorphic rock aggregates in a calcite binder. Towards the outside, a perfectly adhering second layer made only of an aerial binder rich in carbonaceous fragments and two outermost very-thin limewater layers can be distinguished [32]. Rising damp phenomena are visible on the masonry, and inside the wall structures show several degradation phenomena such as erosion, exfoliation, cracks, detachment of the plaster, and saline efflorescence. Over time, all of these conditions increased the vulnerability of the structural materials to biological attacks (Figure 1g), promoting specific microbial colonization within the relative effects that their metabolic activity exerts on stone surfaces.
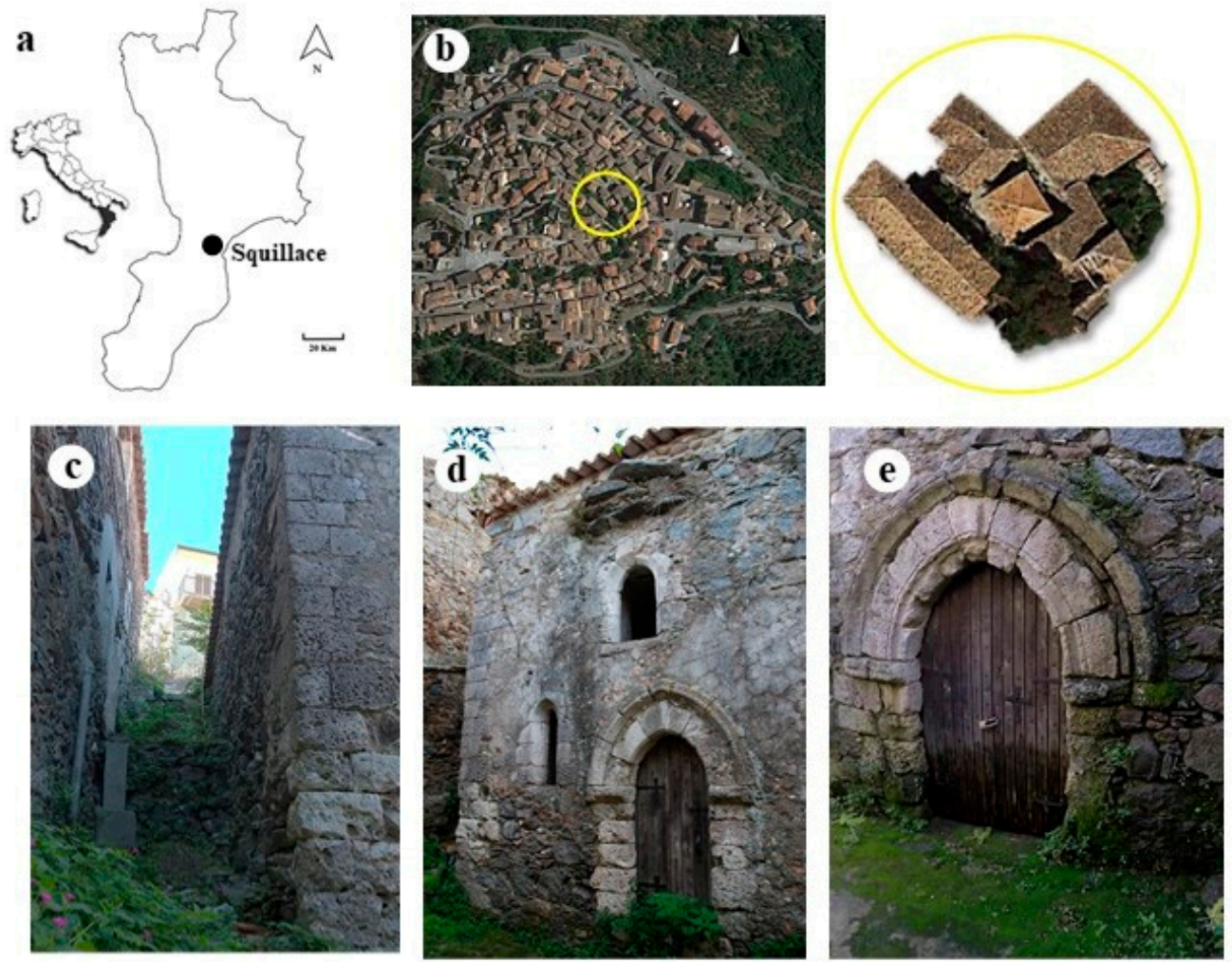

Figure 1. Cont. 

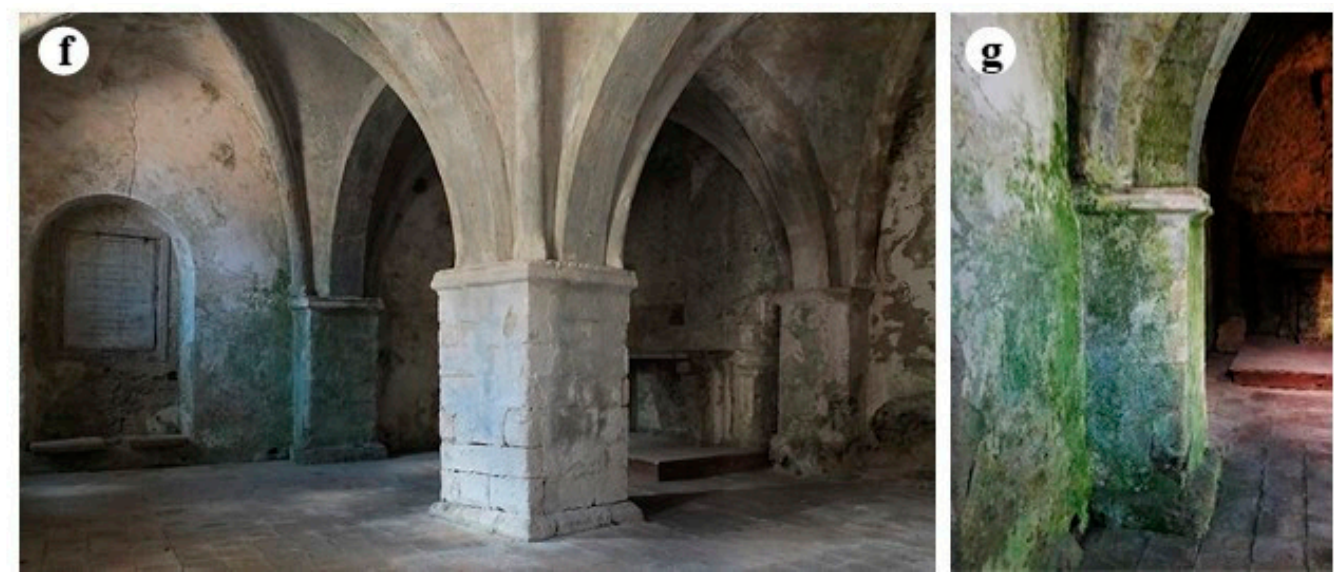

Figure 1. Study site: (a) localization of Squillace (Calabria, South Italy); (b) aerial view of the old village-the square roof of the building is visible in the center of the yellow circle; (c) south façade; (d) detail of east façade; (e) main entrance on north façade-rising damp phenomenon is visible on the door; (f) internal room; (g) detail of the south wall where biological patinas are visible.

\subsection{Sampling and Analysis}

\subsubsection{Higher Plants}

In this study, floristic data are based on collections and field observations carried out between spring and autumn 2017, whose preliminary results are reported in a previous contribution [33]. For each accessible plant species observed on the façades, the building perimeter, and the embankments, (Figure 2), one sample was harvested, preserving the substrate. A detailed photographic documentation has been produced, especially to obtain details on non-sampled species which are difficult to reach. All plant voucher specimens were deposited in the herbarium of Plant Biosystem Laboratory (University of Calabria, Unical). The identification of species was carried out based on Pignatti [34,35] and Tutin [36]. In addition, internet-based databases, such as Portal to the Flora of Italy http:/ / dryades. units.it/cercapiante/index.php (accessed on 14 March 2018) and Actaplantarum https: / /www.actaplantarum.org (accessed on 14 March 2018), were used. For each observed specimen, the growth substrate and the position of the plants in respect to the building have been recorded, as well as the family and the initials of the plant life form according to Raunkiaer's classification [37]. For each taxon, the Hazard Index (HI) [38,39] was specified. This numerical index, ranging from 0 (minimal hazard) to 10 (high hazard), describes the level of danger of each species based on specific morphological characteristics and relative to the type of growth. It differs for each species and it is identified by three numerical indices related to the parameters of biological form, invasiveness, and root system [25,37,40]. The sum of these numbers expresses the potential harmfulness of the individual species to the monument and the difficulty of their being mechanically eliminated, as well as their ability to overwhelm other species. 


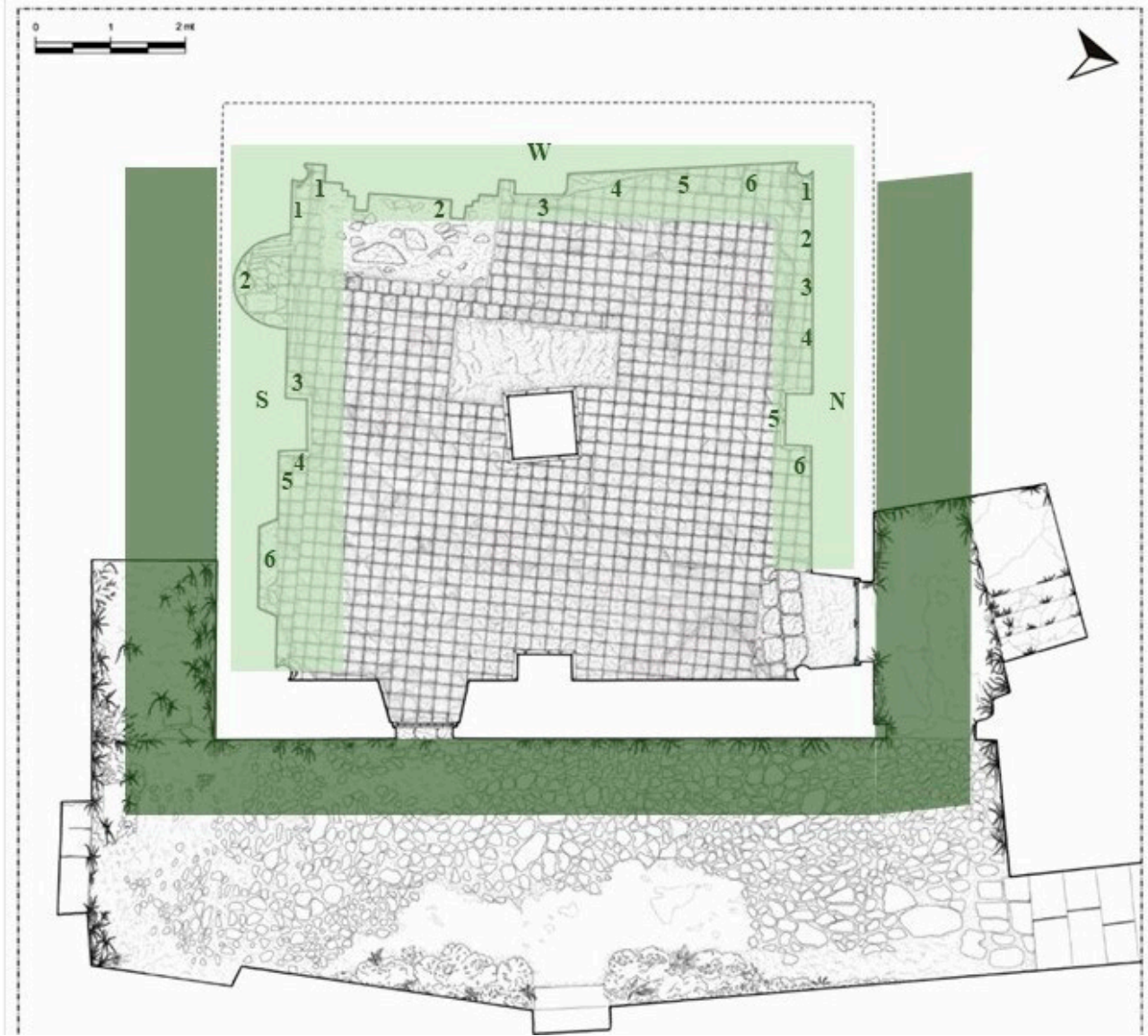

Figure 2. Plan of Santa Maria della Pietà building (Giannotti, 2003) with sampling map. Light green underlines the internal sampled walls ( $\mathrm{N}=$ north; $\mathrm{S}=$ south; and $\mathrm{W}=$ west) with biofilm sampling points. Dark green underlines the external area where higher plants were detected.

\subsubsection{Biofilms}

Biofilms detected on the internal room walls (Figure 2) were collected from plaster, mortar, gypsum, and limestone surfaces. Samples were collected by using adhesive tape strips [41], sterile cotton swabs, and a scalpel, scraping only the superficial microbial layer without affecting the substrate. The field work was carried out in early summer 2017. Six samples were collected from each of the three affected walls (north, south, and west) in correspondence to differentially colored patina and biofilm formations, for a total of 18 samples as described in Table 1.

The east wall showed no biological attack phenomena. Temperature $\left({ }^{\circ} \mathrm{C}\right)$ and relative humidity $(\mathrm{RH} \%)$ parameters were recorded using a thermo-hygrometer data logger at various points around the SMP room during sampling. Samples were stored at $4{ }^{\circ} \mathrm{C}$ and subsequently analyzed by optical microscopy on plate cultures and by molecular techniques according to the Normal Committee recommendations (Normal 9/88) [42]. The morphological identification of cyanobacteria and algae was carried out by optical microscopy according to Anagnostidis and Komárek [43,44], Komárek and Anagnostidis [45,46], Komárek [47], and through use of the CyanoDB site (www.cyanodb.cz accessed on 29 January 2018). To detect phototrophic microorganisms, samples were incubated in a BG11 broth, a universal medium for the cultivation of cyanobacteria and microalgae [48,49], and kept at $22-25{ }^{\circ} \mathrm{C}$ under natural light conditions. Then, several culture dilutions (from $10^{-1}$ to $10^{-5}$ ) were used in order to select phototrophic single-taxon cultures. To characterize fungi, a solid MEA [50] was used as a selective medium for the detection, isolation, and enumeration of yeasts and molds. 
Table 1. Biofilm samples collected from the internal walls of Santa Maria della Pietà. The number of collected samples for each wall $(n=6)$, the macroscopical aspect of the colonization, the sampling point position, the relative surface material composition, and the sampling modality were specified. ( $\mathrm{N}=$ north; $\mathrm{S}=$ south; and $\mathrm{W}=$ west).

\begin{tabular}{|c|c|c|c|c|c|}
\hline Wall & Sample & Type of Colonization & Position & Surface Material & Sampling Modality \\
\hline \multirow{6}{*}{ North $(n=6)$} & N1 & Brownish compact & Corner column & Limestone & Swab/Adhesive Tape \\
\hline & N2 & Dull green compact & Wall & Mortar & Scalpel \\
\hline & N3 & Yellowish green patina & Wall & Mortar & Swab/Adhesive Tape \\
\hline & N4 & Brownish patina & Corner column & Limestone & Swab/Adhesive Tape \\
\hline & N5 & Light green compact & Semi-pillar & Plaster & Scalpel \\
\hline & N6 & Dull green thick & Wall & Plaster & Scalpel \\
\hline \multirow{6}{*}{ South $(n=6)$} & S1 & Greyish green powdery & Wall & Mortar & Swab/Adhesive Tape \\
\hline & $\mathrm{S} 2$ & Yellowish green compact & Niche & Plaster & Scalpel \\
\hline & S3 & Olive green patina & Wall & Plaster & Swab/Adhesive Tape \\
\hline & S4 & Dull green thick & Semi pillar & Plaster & Swab/Adhesive Tape \\
\hline & S5 & Bright green thick & Wall & Plaster & Scalpel \\
\hline & S6 & Dark brown patina & Plaster plate & Gypsum & Swab \\
\hline \multirow{6}{*}{$\begin{array}{l}\text { West } \\
(n=6)\end{array}$} & W1 & Bright green thick & Corner column & Limestone & Swab/Adhesive Tape \\
\hline & W2 & White greysh spongy & Wall & Mortar & Scalpel \\
\hline & W3 & Dull green thick & Wall & Plaster & Scalpel \\
\hline & W4 & Brownish green compact & Wall & Mortar & Swab/Adhesive Tape \\
\hline & W5 & Greyish green spongy & Wall & Mortar & Scalpel \\
\hline & W6 & Light green spongy & Wall & Mortar & Scalpel \\
\hline
\end{tabular}

For molecular analysis, total DNA was extracted using the CTAB (cetyltrimethylammonium bromide) method [51]. PCR amplification was performed using the universal primers for cyanobacteria 16S CYA359 (5'-GGG GAA TYT TCC GCA ATG-3') and CYA781 (5'-GAC TAC AGG GGT ATC TAA TCC CTT-3'), and ITS and 5.8S primers for fungi, ITS1F (5'-CTT GGT CAT TTA GAG GAA GTA A-3') [52] and ITS4 (5'-CAG GAG ACT TGT ACA CGG TCC AG-3') [53]. The PCR reaction was carried out using PCR Master Mix (Bioline Inc., Boston, MA, USA) in a $25 \mu \mathrm{L}$ volume (DNA template: $1 \mu \mathrm{L}$, buffer Master mix: $10 \mu \mathrm{L}$, primer: $0.5 \mathrm{pmoL}$ each, $\mathrm{MgCl}_{2}$ : $1 \mu \mathrm{L}$ ). The thermal cycler used was a Biometra Thermal Cycler (MJ Research Inc., Watertown, MA, USA). We used the following program for cyanobacteria: $5 \mathrm{~min}$ denaturation at $94{ }^{\circ} \mathrm{C}$, followed by 30 cycles of 45 s denaturation at $94{ }^{\circ} \mathrm{C}, 45 \mathrm{~s}$ annealing at $55^{\circ} \mathrm{C}$, and $1 \mathrm{~min}$ extension at $72^{\circ} \mathrm{C}$; and for fungi: 3 min denaturation at $94{ }^{\circ} \mathrm{C}$, followed by 35 cycles of $30 \mathrm{~s}$ denaturation at $94{ }^{\circ} \mathrm{C}, 1 \mathrm{~min}$ annealing at $55^{\circ} \mathrm{C}$, and $45 \mathrm{~s}$ extensions at $72{ }^{\circ} \mathrm{C}$. For both programs, ten minutes at $72{ }^{\circ} \mathrm{C}$ was used as a final extension step.

A kit QIAquick ${ }^{\circledR}$ PCR Purification (QIAGEN Sciences Inc, Germantown, US) has been used for PCR product purification and the sequence reactions were performed at BMR Genomics in Padova (Italy). All sequences were edited using BioEdit 7.2 software (free download from https://bioedit.software.informer.com accessed on 1 November 2021), and the nucleotide sequence similarity was determined using the BLAST algorithm implemented on NCBI tools (www.ncbi.nlm.nih.gov/blast accessed on 23 May 2019), using 97\% as percentage similarity cut-off value.

Alpha diversity indexes (observed taxa richness, Chao1, Shannon and Simpson), frequently utilized to assess the diversity on biofilm-colonized surfaces [54,55], were estimated for each sampled wall using the package "phyloseq" [56] implemented in R environment [57].

\section{Results}

\subsection{Higher Plants}

Seventeen species of vascular plants belonging to 13 Angiosperm families and one species of Pteridophyta, were recorded in the outdoor area. The most represented families are Asteraceae (3 species), Rosaceae ( 2 species) and Urticaceae ( 2 species). The life form spectrum shows a prevalence of Hemicryptophytes (39\%) followed by Phanerophytes and 
Geophytes (22\%), Therophytes (11\%), and Chamaephytes (6\%) (Figure 3a). A total of $61 \%$ of the species are somewhat hazardous (HI 4-6), 22\% are very hazardous (HI 7-10) and 17\% are not very hazardous (HI 0-3) (Figure 3b). Ailanthus altissima (HI 10), Ficus carica (HI 10), Rubus ulmifolius (HI 8), and Sambucus nigra (HI 7) were the most dangerous species. The most widespread species are Mirabilis jalapa (HI 6), Parietaria judaica (HI 5), and Urtica dioica (HI 5). All identified species are frequent throughout the Mediterranean region, and grow well in ruderal environments. Most of them occur on embankments and façades, almost equally distributed on horizontal and vertical surfaces. Table 2 shows the inventory of the plant species detected at the study site where no endemic species were found.
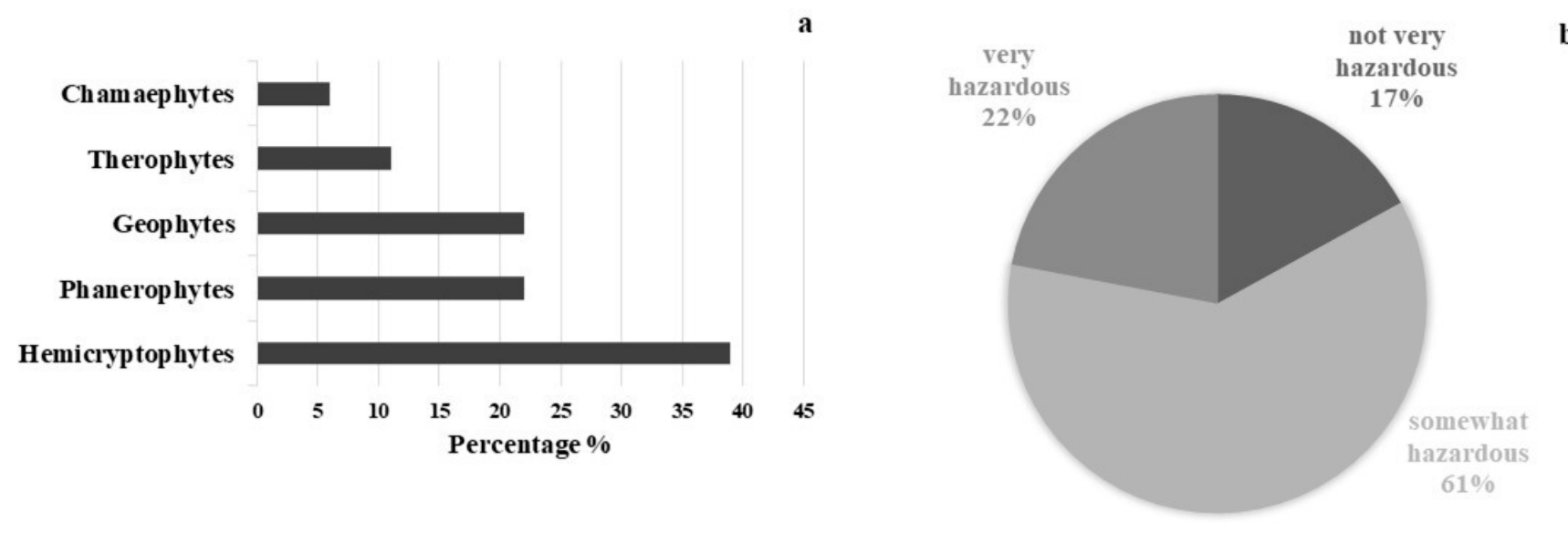

b

Figure 3. Life form spectrum of plant species detected, following $\mathrm{R}$ classification system (a), and amount in percentage of plant species following Hazard Index (b).

Table 2. Inventory of the vascular flora at the study site. For each plant species, here is reported the name of the species, the family, the Raunkiaer's life form, the Hazard Index (HI), the exposure (north, west, east and south), the occurrences on vertical (V) and horizontal $(\mathrm{H})$ surfaces, and the position in relation to the building.

\begin{tabular}{|c|c|c|c|c|c|c|}
\hline Name & Family & Life Form & HI & Exposure & Inclination & Position \\
\hline Ailanthus altissima (Mill.) Swingle & Simaroubaceae & P scap & 10 & $S$ & $\mathrm{H}$ & Embankment \\
\hline Anogramma leptophylla (L.) & Pteridaceae & Ch pulv & 0 & $\mathrm{~N}$ & $\mathrm{~V}$ & Wall \\
\hline Diplotaxis tenuifolia (L.) Dc. & Brassicaceae & H scap & 5 & $\mathrm{~N} / \mathrm{E}$ & $\mathrm{H}$ & Wall perimeter \\
\hline Erigeron canadensis L. & Asteraceae & T scap & 4 & $\mathrm{~N} / \mathrm{E}$ & $\mathrm{H}$ & Wall perimeter \\
\hline Ficus carica L. & Moraceae & P scap & 10 & $\mathrm{~N}$ & $\mathrm{H}, \mathrm{V}$ & Embankment, Wall \\
\hline Mirabilis jalapa L. & Nyctaginaceae & G bulb & 6 & $\mathrm{E}$ & $\mathrm{H}$ & Wall \\
\hline Parietaria judaica L. & Urticaceae & H scap & 5 & $\mathrm{~N} / \mathrm{E} / \mathrm{S}$ & $\mathrm{V}, \mathrm{H}$ & Ubiquitous \\
\hline Phytolacca americana $\mathrm{L}$. & Phytolaccaceae & G rhiz & 6 & $\mathrm{~N} / \mathrm{E}$ & $\mathrm{H}, \mathrm{V}$ & Embankment, Wall \\
\hline Picris hieracioides L. & Asteraceae & H scap & 6 & $\mathrm{E}$ & $\mathrm{V}$ & Wall \\
\hline Rubus ulmifolius Schott. & Rosaceae & $P$ caesp & 8 & $S$ & $\mathrm{H}, \mathrm{V}$ & Embankment, Wall \\
\hline Sambucus nigra L. & Adoxaceae & P caesp & 7 & $\mathrm{~N}$ & $\mathrm{H}$ & Embankment \\
\hline Sanguisorba minor Scop. & Rosaceae & H scap & 6 & $\mathrm{E}$ & $\mathrm{V}$ & Wall \\
\hline Smyrnium olusatrum (L.) & Apiaceae & $\mathrm{H}$ bienn & 3 & $\mathrm{~N}$ & $\mathrm{H}$ & Embankment \\
\hline Sorghum halepense (L.) Pers. & Poaceae & G rhiz & 6 & $\mathrm{E}$ & $\mathrm{V}$ & Wall \\
\hline Taraxacum officinale Web. & Asteraceae & $\mathrm{H}$ ros & 6 & $\mathrm{~N} / \mathrm{E}$ & $\mathrm{H}$ & Wall perimeter \\
\hline Umbilicus rupestris (Salisb.) Dandy & Crassulaceae & G bulb & 5 & $\mathrm{~N}$ & $\mathrm{H}$ & Embankment \\
\hline Urtica dioica $\mathrm{L}$. & Urticaceae & H scap & 5 & $\mathrm{~N} / \mathrm{E} / \mathrm{S}$ & $\mathrm{V}, \mathrm{H}$ & Ubiquitous \\
\hline Veronica polita Fr. & Plantaginaceae & T scap & 3 & $\mathrm{~N} / \mathrm{E}$ & $\mathrm{H}$ & Wall perimeter \\
\hline
\end{tabular}

\subsection{Biofilms}

The temperatures recorded across all internal sampling points ranged between $18^{\circ} \mathrm{C}$ (west wall) and $23^{\circ} \mathrm{C}$ (east wall), while the relative humidity, in the same points, ranged from 70 to $65 \%$. Direct microscopical observation of raw samples and fresh fragments from cultures, revealed that the collected biofilms were heterogeneous in species composition and mainly formed by fungi, cyanobacteria and Chlorophyta. Overall, the highest 
amounts of different species were detected in south-wall samples. The fungal community shows a total of 11 taxa all represented by Ascomycota phylum. Penicillium was the most represented genus reported as dominant in almost all collected samples, followed by the genus Alternaria. Among other species, Engyodontium album was isolated in samples W5 and W6, Geosmithia sp. in N6, and Periconia macrospinosa in S1 (Table 1). In the samples $\mathrm{N} 4$ and W2, biofilms were formed only by the growth of fungi, without phototrophic microorganism association. In N4, the brownish patina was also probably due to the presence of Stachybotrys chartarum hyphae and spores [58]. In W2, Lecanicillium sp. was found on a white/grey spongy alteration on the wall, probably due to the growth of white mycelia. Twenty new genetic sequences of fungal taxa (Table 3) and Cyanobacteria (Table 4) were produced and deposited on the GenBank public repository under accession numbers OK356512-OK356522 and OK382066-OK382074, respectively.

Table 3. Genus and species of fungi examined and sequenced in biofilm samples. GenBank accessions numbers, sequences length in base pair (bp), and the reference samples are reported here.

\begin{tabular}{cccc}
\hline Genus/Species & Accession Number & bp & Sample \\
\hline Alternaria alternata & OK356512 & 540 & S1 \\
Alternaria infectoria & OK356513 & 532 & N5 \\
Engyodontium album & OK356514 & 562 & W5/W6 \\
Geosmithia sp. & OK356515 & 589 & N6 \\
Lecanicillium sp. & OK356516 & 602 & W2 \\
Penicillium brevicompactum & OK356517 & 547 & S1 \\
Penicillium chrysogenum & OK356518 & 544 & W $4 /$ W5 \\
Penicillium glabrum & OK356519 & 529 & S4 \\
Penicillium sumatrense & OK356520 & 539 & S1 \\
Periconia macrospinosa & OK356521 & 522 & N4 \\
Stachybotris chartarum & OK356522 & 528 &
\end{tabular}

Table 4. List of identified phototrophic taxa in biofilm samples. Identification methods, GenBank accessions numbers, and localization of samples are reported.

\begin{tabular}{|c|c|c|c|c|c|c|}
\hline Cyanophyta & Class & Family & Genus & Identification & Acc. No. & Position \\
\hline & Cyanophyceae & Chroococcidiopsidaceae & Chroococcidiopsis & morphological & & $\mathrm{N}, \mathrm{W}$ \\
\hline & Cyanophyceae & Stigonemataceae & Stigonema & morphological & & $\mathrm{S}, \mathrm{N}$ \\
\hline & Cyanophyceae & Oscillatoriaceae & Phormidium & molecular & OK382073 & S \\
\hline & Cyanophyceae & Oscillatoriaceae & Oscillatoria & morphological & & $\mathrm{N}$ \\
\hline & Cyanophyceae & Leptolyngbyaceae & Leptolyngbya & molecular & $\begin{array}{l}\text { OK382066- } \\
\text { OK382072 }\end{array}$ & $\mathrm{N}, \mathrm{S}, \mathrm{W}$ \\
\hline & Cyanophyceae & Prochlorotrichaceae & Nodosilinea & molecular & OK382074 & $\mathrm{N}, \mathrm{W}$ \\
\hline & Cyanophyceae & Schizotrichaceae & Schizothrix & morphological & & S \\
\hline & Cyanophyceae & Nostocaceae & Nostoc & morphological & & $\mathrm{S}, \mathrm{N}$ \\
\hline Chiorophyta & Trebouxiophyceae & Chlorellaceae & Chlorella & morphological & & S. W N \\
\hline & Trebouxiophyceae & Prasiolaceae & Stichococcus & morphological & & S, W \\
\hline & Chlorophyceae & Chlorococcaceae & Chlorococcum & morphological & & $S, W$ \\
\hline & Ulvophyceae & Cladophoraceae & Cladophora & morphological & & $S$ \\
\hline
\end{tabular}

The identification of cultured cyanobacteria and microalgae was problematic because of the difficulty in reproducing in vitro the optimal growth conditions and because of the resistance to culture exhibited by phototrophic microorganisms, which was dependent on the choice of solid or liquid media $[59,60]$. Furthermore, cyanobacteria showed a big phenotypic plasticity depending on the environmental and culture conditions [61]. Besides this, it is generally not easy to discern their morphological characteristics, making their identification quite difficult. However, in most cases phototroph growth was obtained, and the serial dilution method was useful to render isolated colonies macroscopically visible after two months of cultivation. Cyanobacteria and green algae, both filamentous and spherical (Table 4), were identified by direct microscopic observation and with application 
of molecular methodologies. The highest numbers of photoautotrophs are represented by filamentous genera. Molecular analyses allowed the identification of three cyanobacteria genera, Phormodium (OK382073), Nodosilinea (OK382074), and Leptolyngbya (Figure 4a), with the presence of seven different isolates with accession numbers from OK382066 to OK382072 (Table 4). The other genera, identified on a morphological basis, are mostly filamentous (Stigonema, Oscillatoria, Schizothrix, and Nostoc) (Figure 4b), with one coccoid (Chroococcidiopsis). Chlorophyta were represented by two Trebouxiophyceae (Chlorella and Stichococcus) (Figure 4c), one Chlorophyceae (Chlorococcum), and one Ulvophyceae (Cladophora). Several diatoms were also detected. Figure $4 \mathrm{~d}$ shows the presence of Eunotia. The diversity index shows a higher amount of biodiversity in the south-oriented wall rather than the northern- and western-oriented walls, which show similar values of diversity (Table 5, Figure 5a) in concordance with the abundance bar plot (Figure 5b).
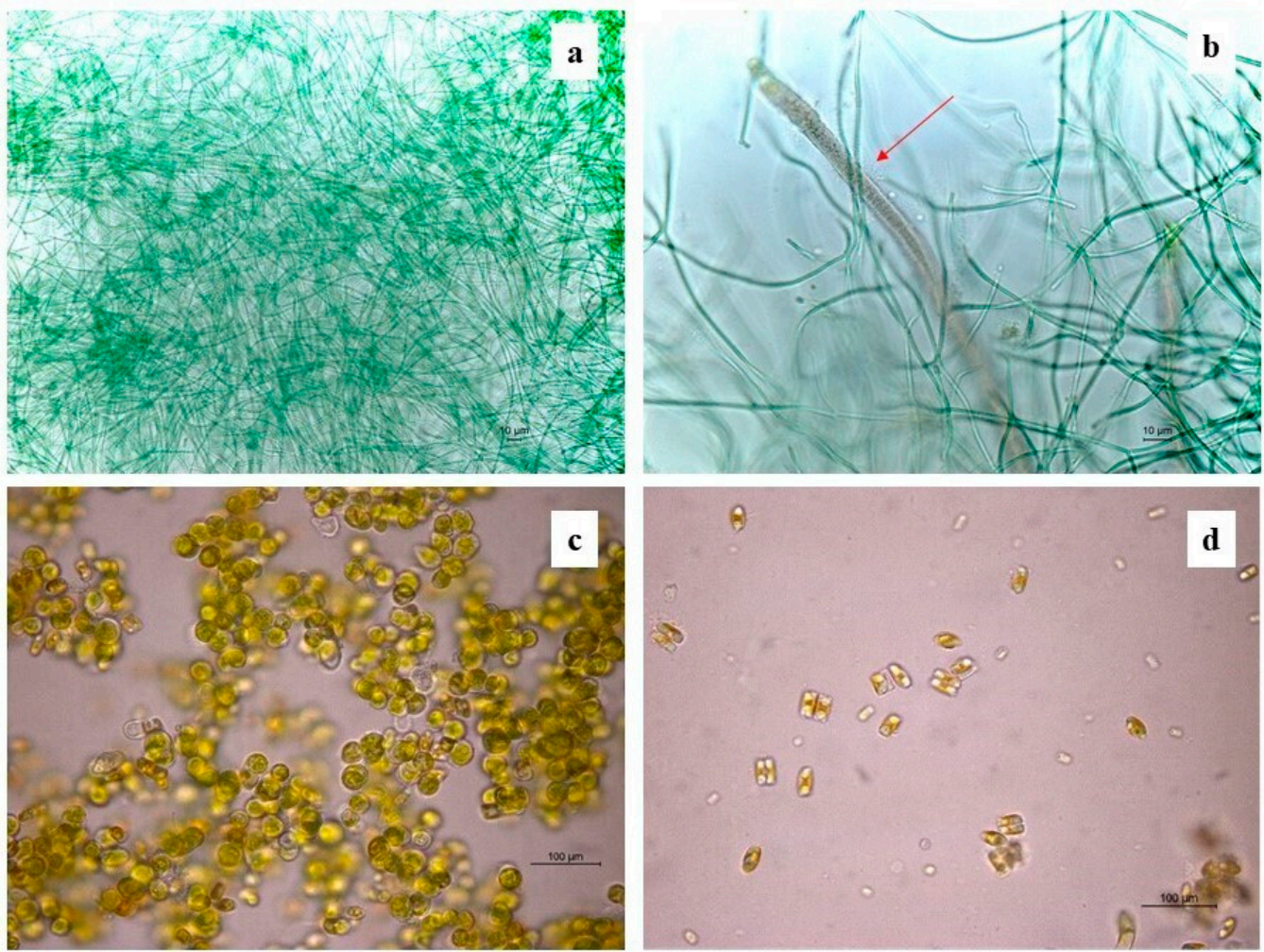

Figure 4. Some identified phototrophic taxa under the optical microscope: (a) Leptolyngbya; (b) Schizothrix (red arrow); (c) Chlorella; (d) Eunotia.

Table 5. Alpha diversity indexes: Observed taxa richness (Species and Species sp.); Chao 1 Index; Shannon Index; and Simpson Index.

\begin{tabular}{ccccc}
\hline Sampled Wall & Observed & Chao 1 & Shannon & Simpson \\
\hline NORTH & 10 & 17.00000 & 2.205598 & 0.8775510 \\
\hline SOUTH & 15 & 19.66667 & 2.614589 & 0.9201389 \\
\hline WEST & 10 & 10.50000 & 2.232694 & 0.8864266 \\
\hline
\end{tabular}



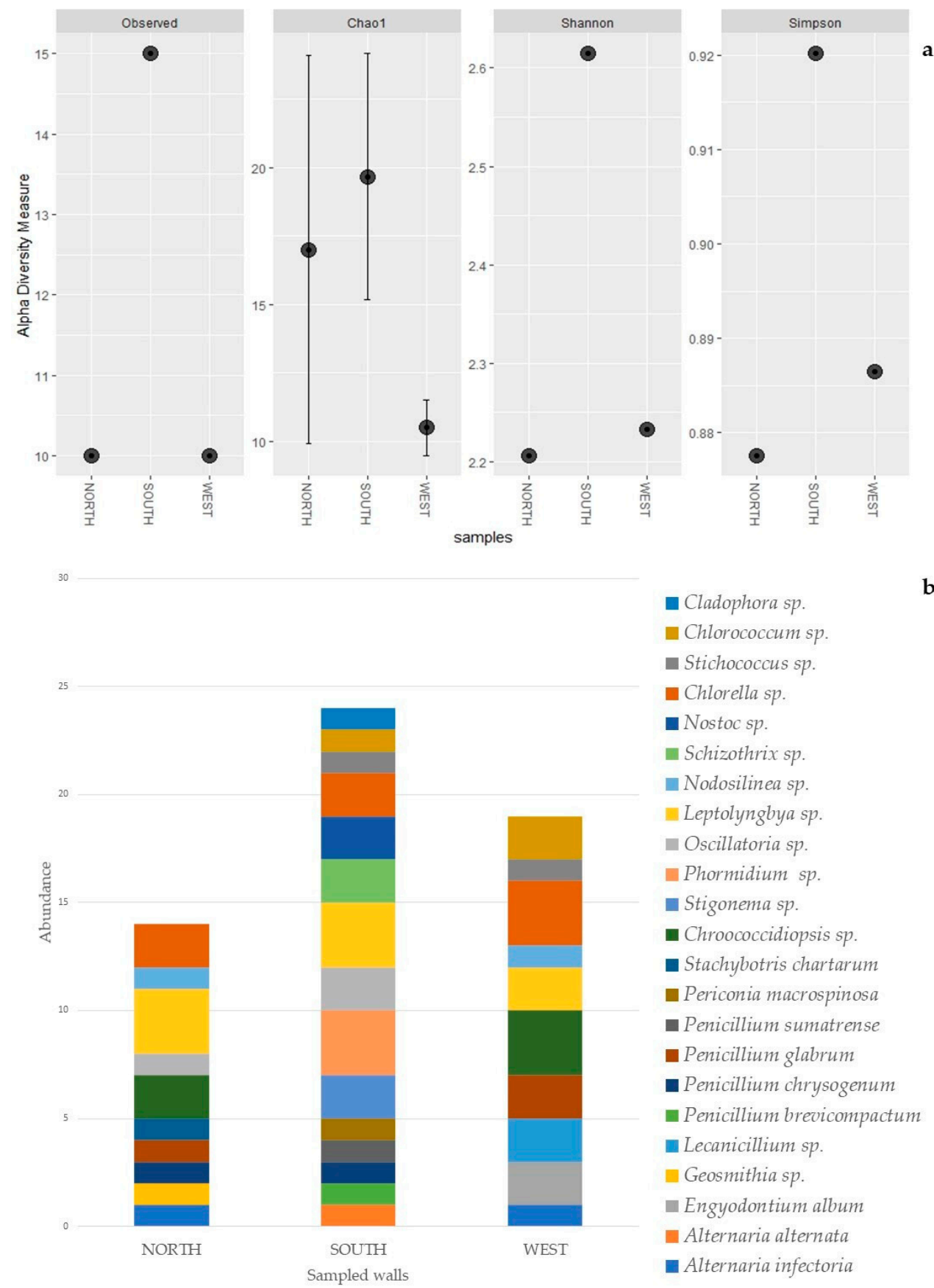

Figure 5. Alpha diversity plot: observed taxa richness, Chao 1, Shannon and Simpson, for each sampled wall (a). Abundance bar plot of biofilm's taxa composition, per species, for each sampled wall (b).

\section{Discussion}

The biological analysis and the floristic investigation highlighted a significant variety of microorganisms and higher plants species throughout the whole study site. Climatic parameters were almost constant in the room area, with a small variation in proximity of the internal sampling points, where a decrease in temperature and an increase in the relative humidity were recorded. This was presumably due to the distance from the entrance and the few openings on the east-facing wall. Furthermore, the particular exposure of the walls allows the higher plants to proliferate on the embankments in direct contact with the masonry, keeping the internal relative humidity rate constantly quite high, as well as promoting the deterioration process that ruderal plant development exerts on wall structures. In Mediterranean climates, especially during summer, south-facing sides used 
to be drier and warmer than northern sides, and this could limit plant proliferation [62]; however, in our study site, this natural pattern is not completely respected. The singular location of SMP ensures that the surrounding buildings shield the south façade from direct sunlight, and this helps to reduce air and soil temperatures even in the hottest months of the year. This confirms that plant colonization, and also their HI value, strictly depends on particular exposure conditions [12]. In fact, we recorded the highest HI values both on north- and south-facing slopes, where, moreover, mineral salt and nutrient availabilities in the two embankments promote plant proliferation. The damage caused by ruderal plants on monuments is linked to the life forms that significantly affect the Hazard Index [40], and it is mainly related to the characteristics of the root system [63]. We found that the four species with the highest dangerous impact are woody plants all belonging to Phanerophytes, characterized by strong and deep root systems. An individual A. altissima, and a vigorous R. ulmifolius shrub sink their roots into the soil immediately adjacent to the south-facing wall, while F. carica grew against the north-facing wall. Other smaller specimens of F. carica were found growing directly into the stone masonry, as well as several specimens of $S$. nigra, on both the south and north façades. These species, although not very abundant, represent a high risk for the building's walls. When exploring soils in search for water and minerals, plant roots can exert extraordinary pressures in stone materials, detaching and collapsing structures. Several studies [64-66] showed the serious damages caused by A. altissima to wall structures due to its extreme invasiveness and its high ability to develop root systems at a great distance from the rooting point. Furthermore, F. carica, as well as R. ulmifolius, is documented to be a fast-developing species with a strong and deep root system [28] with a fast-spreading capacity for colonizing ruderal environments and ancient walls. The presence of S. nigra on mortar substrates was also documented in other historic buildings in southern Italy [40]. Overall, at our study sites, the flora was dominated by biennial and perennial herbaceous species with a medium Hazard Index. Even if their roots systems are smaller and weaker than that of Phanerophytes, Hemicryptophytes could also be harmful to wall structures because of their high ability to colonize different substrates, even those lacking in nutrients and organic matter [63]. In addition, their presence can create favorable conditions that facilitate shrub and tree seed germination [67] promoting the growth of higher woody plants.

The internal surfaces sampled were mostly calcium carbonate-based. The characteristics of calcareous substrata, such as $\mathrm{pH}$ rate and porosity, are optimal for microbial colonization [68]. Capillary water rise and pores water retention are among the main problems affecting historic masonry buildings, causing material deterioration and even structural problems [69]. Mortar porosity allows the penetration of water and soluble salts coming from the masonry materials themselves [70] and the external adjacent embankments, increasing the susceptibility of the stone surface and creating good indoor conditions for the establishment and development of microbial biofilms. Results showed that the samples collected from the internal walls of our study site included a wide range of microorganisms found in environments characterized by almost constant temperatures throughout the year and quite high humidity levels, such as caves [71], hypogea [72], and grottoes [73]. In order to provide information on the diversity of biofilm microorganisms, the combination of molecular techniques with culture-dependent methods has been used for the first time in the study area. Despite its wide use to detect microorganisms inhabiting historical monuments, cultivation-based approaches are often not sufficient to assess the complete microbial composition [74]. The limit is that most of the microorganisms present in the natural environment are not culturable under laboratory conditions [75], and the sole use of standard cultivation procedures can provide only partial information. Therefore, molecular detection methods represented a powerful tool to better analyze the biodiversity of microorganisms thriving on our study site walls.

The majority of fungi identified in biofilms are among the most common deteriorative agents found on stone materials and in indoor environments. For example, Lecanicillium was found in the air and biofilms of Roman catacombs [76] and in Lascaux cave $[77,78]$, and 
it is classified as an entomopathogen fungal genus often correlated with insect cadavers as well as some species of Engyodontium. Geosmithia is another fungal genus associated with arthropods, especially oak bark beetles [79], and is quite rarely found. Squillace represents one of the two main Sites of Regional Importance for cork oak (Quercus suber L.) conservation areas in Calabria [80], and in the topsoil above the SMP building, some oak specimens are visible. Therefore, it is plausible that the presence of Geosmithia could be a consequence of conidia transport by oak arthropods, corroborating findings from other studies. These results suggest that the composition of the fungal community could be influenced by the activity of arthropods, as well as other animals such as mice and birds [1]. Finding Periconia macrospinosa and Stachybotrys chartarum confirms how the surrounding environment of the building plays an important role in affecting the fungal species selection. These two species are soils and leaf-litter inhabitants and are commonly found in indoor damp environments $[58,81]$. In particular, despite its role in material deterioration being not well known, S. chartarum, also known as "toxic black mold", is associated with human health diseases because of its production of mycotoxins [81,82]. We found that Alternaria and Penicillium mixed in association with Cyanobacteria and green algae, which are considered the first pioneering lithobionts [83] and are the main components of phototrophic biofilms, playing an important role in their formation [84,85]. They indirectly promote the growth of heterotrophic microorganisms, and their association with fungi in complex and wellorganized biofilms often occurs [86]. All phototrophic colonizers identified in this study are commonly found dwelling on different kinds of stone cultural assets and are ecologically typical of wet and humid areas, such as catacombs and hypogean environments [87], as well as monumental fountains [88]. As shown in Table 4, samples from the south wall reported the greatest abundance and variety of microbial associations, even if most of all the identified species were almost ubiquitous on the three sampled walls. Results showed that Leptolyngbya, Chroococcidiopsis, Stigonema, and Nodosilinea among cyanobacteria, and Chlorella, Stichococcus, and Chlorococcum among Chlorophyta, are the most widespread genus (Table 4). Cyanobacteria are entirely represented by filamentous organisms, except for Chroococcidiopsis, a genus characterized by a high resistance to desiccation and radiation, often reported in studies about endolithic growth in rocks [89]. Leptolyngbya is the most represented genus, which shows both morphological and molecular high plasticity. As reported by Komárek [90], the genus Leptolyngbya is "a wide natural cluster (genotype) comprising several species of old traditional genera" with different morphs and ecotypes which make it difficult to classify. Molecular analysis and phylogenetic studies have shown that Leptolyngbya is a polyphyletic genus and the ITS region represents an additional diagnostic tool. The presence of seven isolates reported in this study confirms its heterogeneity at the intrageneric level. Green algae were most represented in samples collected in spots more exposed to light, with Chlorella as most widespread genus, confirming that among green algae, unicellular forms tend to prevail [18]. The presence of Cladophora may be related to the proximity of the sea to the study site, according to results from other studies which reported the presence of Cladophora genus on stone monuments, statues, and historic buildings in European countries along the Mediterranean shoreline [91,92].

The alpha diversity analysis highlighted higher biodiversity values on the southernoriented wall (Table 5). The different index values show similar diversity patterns, except for the Chao 1 index, where the north-oriented wall highlighted a higher value compared to the western wall (Table 5). However, this higher value is accompanied by a wider variance. In fact, this index, rather than the Shannon and the Simpson indexes, is more affected by single taxon observations (singleton) [93]. Chao 1 index results are visible in the abundance bar plot (Figure 5), which, with the same number of taxa, clearly shows higher amounts of singletons for the northern wall compared to the west wall. The higher amount of alpha diversity on the southern wall suggests that a potentially more favorable orientation, combined with several environmental conditions, such as the higher amount of light, may have facilitated the colonization of this wall by more taxa. However, further investigation and a bigger sample size would allow for a more comprehensive picture. 
Knowledge of the colonization abilities of the main biodeteriogenic plant species, their structural and physiological features, and their relationship with the architectural artifact, is necessary to control the proliferation of vascular flora on historic monuments. The choice of the most suitable intervention techniques requires careful analysis, respecting the protection and conservation of the monument while also acknowledging the ecological interest of plant species. On the basis of the species detected at our study site and their position in relation to the walls, few (but effective) interventions might be sufficient for a good cleaning of the outdoor area, in order to stem and control the proliferation of the most dangerous plants, thereby preserving the masonry. Manual eradication and periodical monitoring of herbaceous species with small and not-branched root systems is possible without damaging the substrate in the case of species that grow directly on the walls, paying attention not to remove harmless and protected species, such as Anogramma leptophylla [94]. The cutting of woody species, and applications of herbicide (choosing environmentally friendly methods as much as possible) [63], should be required to eradicate the most harmful specimens. Finally, the periodical cleaning of the north and south slopes might be necessary to minimize the establishment of new species, as well as favoring the drying of the masonry, consequently decreasing the amount of retained moisture, which is one of the main causes of physicochemical deterioration and biological attacks on the internal walls of the SMP.

Stone deterioration by microbial biofilms is a very complex process involving various mechanisms due to microorganism growth and metabolic activity, which often affects the internal structure of the stone substrates and are not always visible by eye. Fungi play a considerable role in the weathering of stone monuments because of their extremely erosive activities through mycelial growth and the production of organic acids and pigments [95]. Photosynthetic microorganisms exert pressure within the stone, changing the water volumes in their gelatinous sheaths during drying and rehydration cycles. The precipitation of oxalates and the mobilization of calcium ions also contribute to the degradation of calcareous substrata [96]. Beyond the characteristic properties of the different microorganism families, biofilm formation itself is a biodeteriogenic factor [24]. This is why the study of EPS production by most frequent biofilm-forming cyanobacteria, such as Leptolyngbya [19], has become of great interest for the better understanding of its role in monument biodegradation. Surface color alterations, mineral dissolution by biogenic acids, increased water retention, mobilization and crystallization of metallic cations, salt efflorescence, and the penetration of fungal hyphae and other endolithic organisms are just some of the factors that could be involved in the gradual decohesion and degradation of the wall surfaces investigated.

\section{Conclusions}

This study represents the first approach of applied botany to the architectural complex of Santa Maria della Pietà of Squillace. The data collected provide an initial but exhaustive assessment to clarify the relationships between the biodeteriogenic potentials of the detected species and the conditions of decay affecting the building. They also contribute to the knowledge of the spontaneous vascular flora that is still poorly investigated in the historical sites of southern Italy. The results of this study, combined with the environmental conditions and the architectural features of the SMP building, lead us to conclude that humidity is the most critical factor that should be looked at with priority in an effective conservation strategy. Therefore, this work is also the basis upon which to set future studies for the development of proper intervention and maintenance methods.

Author Contributions: Conceptualization, A.M.P. and M.E.M.; methodology, A.M.P., M.E.M. and G.P.; software, A.M.P. and M.E.M.; validation, A.M.P.; formal analysis, A.M.P., M.E.M. and G.P.; investigation and data analysis, M.E.M.; writing—original draft preparation, M.E.M.; writingreview and editing, A.M.P., M.E.M. and G.P.; supervision, A.M.P.; project administration, A.M.P. All authors have read and agreed to the published version of the manuscript. 
Funding: This research received no external funding.

Institutional Review Board Statement: Not applicable.

Informed Consent Statement: Not applicable.

Data Availability Statement: Data supporting reported results are available on request. All DNA sequences were submitted on GenBank under Acc. No. OK356512-OK356522 and OK382066- OK382074

Acknowledgments: We thank the architect Giovanni Giannotti who provided important information about the nature of the building materials and kindly helped with the descriptions of the main architectural elements of the study area. We thank Agostino Leone for his support in statistical analysis. We would also thank the three anonymous reviewers and the editor of the manuscript for suggested improvements.

Conflicts of Interest: The authors declare no conflict of interest.

\section{References}

1. Cuzman, O.A.; Tiano, P.; Ventura, S.; Frediani, P. Biodiversity on Stone Artifacts. In The Importance of Biological Interactions in the Study of Biodiversity; InTech: London, UK, 2011; pp. 367-390.

2. Santo, A.; Agostini, B.; Checcucci, A.; Pecchioni, E.; Perito, B. An interdisciplinary study of biodeterioration of the external marbles of Santa Maria del Fiore Cathedral, Florence (IT). In Proceedings of the International Conference Florence Heritech: The Future of Heritage Science and Technologies, Florence, Italy, 14-16 October 2020.

3. Tiano, P. Biodegradation of Cultural Heritage: Decay Mechanisms and Control Methods. In Proceedings of the 9th ARIADNE Workshop "Historic Material and their Diagnostic" ARCCHIP, Prague, Czech Republic, 22-28 April 2002; Available online: http:/ / www.arcchip.cz/w09/w09_tiano.pdf (accessed on 13 December 2021).

4. Gorbushina, A.A. Life on the rocks. Environ. Microbiol. 2007, 9, 1613-1631. [CrossRef]

5. Albertano, P. Cyanobacterial Biofilms in Monuments and Caves. In Ecology of Cyanobacteria II: Their Diversity in Space and Time; Whitton, B.A., Ed.; Springer: Dordrecht, The Netherlands, 2012; pp. 317-343. ISBN 978-94-007-3855-3.

6. Borderie, F.; Denis, M.; Barani, A.; Alaoui-Sossé, B.; Aleya, L. Microbial composition and ecological features of phototrophic biofilms proliferating in the Moidons Caves (France): Investigation at the single-cell level. Environ. Sci. Pollut. Res. 2016, 23, 12039-12049. [CrossRef] [PubMed]

7. Hueck, H. The biodeterioration of materials-An appraisal. Int. Biodeterior. Biodegrad. 2001, 48, 5-11. [CrossRef]

8. Griffin, P.; Indictor, N.; Koestler, R. The biodeterioration of stone: A review of deterioration mechanisms, conservation case histories, and treatment. Int. Biodeterior. 1991, 28, 187-207. [CrossRef]

9. Guillitte, O. Bioreceptivity: A new concept for building ecology studies. Sci. Total. Environ. 1995, 167, 215-220. [CrossRef]

10. Miller, A.; Sanmartín, P.; Pereira-Pardo, L.; Dionísio, A.; Saiz-Jimenez, C.; Macedo, M.; Prieto, B. Bioreceptivity of building stones: A review. Sci. Total. Environ. 2012, 426, 1-12. [CrossRef]

11. Prieto, B.; Silva, B. Estimation of the potential bioreceptivity of granitic rocks from their intrinsic properties. Int. Biodeterior. Biodegrad. 2005, 56, 206-215. [CrossRef]

12. Motti, R.; Bonanomi, G. Vascular plant colonisation of four castles in southern Italy: Effects of substrate bioreceptivity, local environment factors and current management. Int. Biodeterior. Biodegrad. 2018, 133, 26-33. [CrossRef]

13. Pinna, D.; Salvadori, O. Meccanismi Generali Dei Processi Di Biodeterioramento. In La biologia Vegetale per i Beni Culturali. Biodeterioramento e Conservazione; Nardini: Firenze, Italy, 2005; Volume 1, pp. 15-34.

14. Albertano, P.; Altieri, A.; Caneva, G.; Ceschin, S.; Maggi, O.; Nugari, M.P.; Pasquariello, G.; Persiani, A.; Piervittori, R.; Pietrini, M.; et al. Problems of Biodeterioration in Relation to Particular Types of Environments. In Plant Biology for Cultural Heritage: Biodeterioration and Conservation; Caneva, G., Nugari, M.P., Salvadori, O., Eds.; The Getty Conservation Institute: Los Angeles, CA, USA, 2008; pp. 171-218.

15. Caneva, G.; Ceschin, S. Ecology of Biodeterioration. In Plant Biology for Cultural Heritage: Biodeterioration and Conservation; Caneva, G., Nugari, M.P., Salvadori, O., Eds.; The Getty Conservation Institute: Los Angeles, CA, USA, 2009 ; pp. 35-58.

16. Tiano, P.; Accolla, P.; Tomaselli, L. Phototrophic biodeteriogens on lithoid surfaces: An ecological study. Microb. Ecol. 1995, 29, 299-309. [CrossRef]

17. Morton, L.; Surman, S. Biofilms in biodeterioration-A review. Int. Biodeterior. Biodegrad. 1994, 34, 203-221. [CrossRef]

18. Roldán, M.; Hernández Mariné, M. Exploring the secrets of the three-dimensional architecture of phototrophic biofilms in caves. Int. J. Speleol. 2009, 38, 41-53. [CrossRef]

19. Bellezza, S.; Paradossi, G.; De Philippis, R.; Albertano, P. Leptolyngbya strains from Roman hypogea: Cytochemical and physico-chemical characterisation of exopolysaccharides. Environ. Boil. Fishes 2003, 15, 193-200. [CrossRef]

20. Roy, P.K.; Ha, A.J.-W.; Mizan, F.R.; Hossain, I.; Ashrafudoulla; Toushik, S.H.; Nahar, S.; Kim, Y.K.; Ha, S.-D. Effects of environmental conditions (temperature, $\mathrm{pH}$, and glucose) on biofilm formation of Salmonella enterica serotype Kentucky and virulence gene expression. Poult. Sci. 2021, 100, 101209. [CrossRef] [PubMed] 
21. Roy, P.K.; Mizan, F.R.; Hossain, I.; Han, N.; Nahar, S.; Ashrafudoulla; Toushik, S.H.; Shim, W.-B.; Kim, Y.-M.; Ha, S.-D. Elimination of Vibrio parahaemolyticus biofilms on crab and shrimp surfaces using ultraviolet $\mathrm{C}$ irradiation coupled with sodium hypochlorite and slightly acidic electrolyzed water. Food Control 2021, 128, 108179. [CrossRef]

22. Crispim, C.; Gaylarde, C. Cyanobacteria and Biodeterioration of Cultural Heritage: A Review. Microb. Ecol. 2005, 49, 226-235. [CrossRef]

23. Walker, J.J.; Pace, N.R. Endolithic Microbial Ecosystems. Annu. Rev. Microbiol. 2007, 61, 331-347. [CrossRef] [PubMed]

24. Rivera, L.E.C.; Ramos, A.P.; Sánchez, J.I.C.; Serrano, M.E.D. Origin and Control Strategies of Biofilms in the Cultural Heritage. In Antimicrobials, Antibiotic Resistance, Antibiofilm Strategies and Activity Methods; IntechOpen: London, UK, 2019; pp. 51-74. [CrossRef]

25. Dornieden, T.; Gorbushina, A.A.; Krumbein, W.E. Patina. In Of Microbes and Art: The Role of Microbial Communities in the Degradation and Protection of Cultural Heritage; Ciferri, O., Tiano, P., Mastromei, G., Eds.; Springer: Boston, MA, USA, 2000; pp. 105-119. ISBN 978-1-4615-4239-1.

26. Eyssautier-Chuine, S.; Vaillant-Gaveau, N.; Charpentier, E.; Reffuveille, F. Comparison of biofilm development on three building and restoration stones used in French monuments. Int. Biodeterior. Biodegrad. 2021, 165, 105322. [CrossRef]

27. Sterflinger, K.; Piñar, G. Microbial deterioration of cultural heritage and works of art-Tilting at windmills? Appl. Microbiol. Biotechnol. 2013, 97, 9637-9646. [CrossRef]

28. Caneva, G.; Galotta, G.; Cancellieri, L.; Savo, V. Tree roots and damages in the Jewish catacombs of Villa Torlonia (Roma). J. Cult. Herit. 2009, 10, 53-62. [CrossRef]

29. Ferraro Pelle, C. La Cosiddetta Chiesetta Di, S. Maria Della Pietà a Squillace: Problemi Ed Aspetti Del Restauro in Un Prezioso Esempio Di Architettura Gotica Calabrese. In Proceedings of the I Beni Culturali e le Chiese di Calabria, Convegno Ecclesiale Regionale Promosso dalla Conferenza Episcopale Calabra, Reggio Calabria-Gerace, Italy, 24-26 October 1980; Volume 37, pp. 477-479.

30. Mafrici, M. Squillace e Il Suo Castello Nel Sistema Difensivo Calabrese; Nuove Edizioni Barbaro: Delianuova, Italy, 1981.

31. Kottek, M.; Grieser, J.; Beck, C.; Rudolf, B.; Rubel, F. World Map of the Köppen-Geiger climate classification updated. Meteorol. Z. 2006, 15, 259-263. [CrossRef]

32. Giannotti, G.B. Analisi Stratigrafiche Sugli Intonaci Di, S. Maria Della Pietà Di Squillace. Archit. Catanzaro News $2009,1,40-41$.

33. Mascaro, M.E.; Pellegrino, G.; De Rose, I.; Palermo, A.M. Contribution to the Knowledge of Biodeteriogenic Flora on Three Historical Calabrian (Southern Italy) Churches. Open J. Ecol. 2021, 11, 287-300. [CrossRef]

34. Pignatti, S. Flora d'Italia; Edagricole: Bologna, Italy, 1982.

35. Pignatti, S.; Guarino, R.; Rosa, M.L. Flora d'Italia; Flora d'Italia in 4 Volumi: Flora Digitale; Edagricole-New Business Media: Milano, Italy, 2017; ISBN 978-88-506-5243-3.

36. Tutin, T.G.; Burges, N.A.; Chater, A.O.; Edmondson, J.R.; Heywood, V.H.; Moore, D.M.; Valentine, D.; Walters, S.; Webb, D. Flora Europaea, 2nd ed.; Cambridge University Press: Cambridge, UK, 1993; Volume 1.

37. Raunkiær, C. Life Forms of Plants and Statistical Plant Geography. In History of Ecology; Arno Press: New York, NY, USA, 1977; ISBN 978-0-405-10418-3.

38. Signorini, M. L'indice Di Pericolosità: Un Contributo Del Botanico al Controllo Della Vegetazione Infestante Nelle Aree Monumentali. Inf. Bot. Ital. 1996, 28, 7-14.

39. Signorini, M.A. Lo Studio e Il Controllo Della Vegetazione Infestante Nei Siti Archeologici. Una Proposta Metodologica. In L'Area Archeologica di Fiesole. Rilievi e Ricerche per la Conservazione; Marino, L., Nenci, C., Eds.; Alinea: Firenze, Italy, $1995 ;$ pp. 41-46.

40. Motti, R.; Stinca, A. Analysis of the biodeteriogenic vascular flora at the Royal Palace of Portici in southern Italy. Int. Biodeterior Biodegrad. 2011, 65, 1256-1265. [CrossRef]

41. Urzì, C.; DE Leo, F. Sampling with adhesive tape strips: An easy and rapid method to monitor microbial colonization on monument surfaces. J. Microbiol. Methods 2001, 44, 1-11. [CrossRef]

42. Normal Commissione. Normal 9/88 Microflora Autotrofa Ed Eterotrofa: Tecniche Di Isolamento in Coltura; CNR-ICR: Roma, Italy, 1990

43. Anagnostidis, K.; Komárek, J. Modern Approach to the Classification System of Cyanophytes. 3-Oscillatoriales. Algol. Stud. Für Hydrobiol. Suppl. Vol. 1988, 50-53, 327-472.

44. Anagnostidis, K.; Komárek, J. Modern Approach to the Classification System of Cyanophytes. 1-Introduction. Algol. Stud. Hydrobiol. Suppl. Vol. 1985, 38-39, 291-302.

45. Komarek, J.; Anagnostidis, K. Modern Approach to the Classification System of Cyanophytes 4-Noazstocales. Arch. Hydrobiol. Suppl. Monogr. Beitr. 1989, 82, 247-345.

46. Komárek, J.; Anagnostidis, K. Modern Approach to the Classification System of Cyanophytes. Chroococcales. Algol. Stud. Hydrobiol. Suppl. Vol. 1986, 43, 157-226.

47. Komárek, J. Cyanoprokaryota Teil/3rd Part: Heterocytous Genera; Springer Spektrum: Berlin, Germany, 2013.

48. Castenholz, R.W. Culturing methods for cyanobacteria. In Methods in Enzymology; Elsevier BV: Amsterdam, The Netherlands, 1988; Volume 167, pp. 68-93.

49. Preisig, H.R.; Andersen, R.A. Historical Review of Algal Culturing Techniques. Algal Cult. Tech. 2005, 65, 79-82.

50. Drug Administration. Bacteriological Analytical Manual; AOAC International: Gaithersburg, MD, USA, 1995; ISBN 0-935584-59-5.

51. Doyle, J.J.; Doyle, J.L. A rapid DNA isolation procedure for small quantities of fresh leaf tissue. Phytochem. Bull 1987, $19,11-15$. 
52. Gardes, M.; Bruns, T.D. ITS primers with enhanced specificity for basidiomycetes-Application to the identification of mycorrhizae and rusts. Mol. Ecol. 1993, 2, 113-118. [CrossRef]

53. White, T.; Bruns, T.; Lee, S.; Taylor, J. Amplification and Direct Sequencing of Fungal Ribosomal RNA Genes for Phylogenetics Available online: http:/ / pdf.xuebalib.com:1262/3x0d5gC6z4eF.pdf (accessed on 4 October 2018).

54. Coelho, C.; Mesquita, N.; Costa, I.; Soares, F.; Trovão, J.; Freitas, H.; Portugal, A.; Tiago, I. Bacterial and Archaeal Structural Diversity in Several Biodeterioration Patterns on the Limestone Walls of the Old Cathedral of Coimbra. Microorganisms 2021, 9 , 709. [CrossRef] [PubMed]

55. Romani, M.; Carrion, C.; Fernandez, F.; Intertaglia, L.; Pecqueur, D.; Lebaron, P.; Lami, R. High bacterial diversity in pioneer biofilms colonizing ceramic roof tiles. Int. Biodeterior. Biodegrad. 2019, 144, 144. [CrossRef]

56. McMurdie, P.J.; Holmes, S. phyloseq: An R Package for Reproducible Interactive Analysis and Graphics of Microbiome Census Data. PLoS ONE 2013, 8, e61217. [CrossRef]

57. R Core Team R. A Language and Environment for Statistical Computing; R Foundation for Statistical Computing: Vienna, Austria, 2021

58. Li, Y.; Huang, Z.; Petropoulos, E.; Ma, Y.; Shen, Y. Humidity governs the wall-inhabiting fungal community composition in a 1600-year tomb of Emperor Yang. Sci. Rep. 2020, 10, 8421. [CrossRef]

59. Laiz, L.; Gonzalez, J.; Saiz-Jimenez, C. Microbial Communities in Caves: Ecology, Physiology, and Effects on Paleolithic Paintings In Art, Biology, and Conservation: Biodeterioration of Works of Art; MetPublications: New York, NY, USA, 2003; pp. $210-215$.

60. Sigler, W.V.; Bachofen, R.; Zeyer, J. Molecular characterization of endolithic cyanobacteria inhabiting exposed dolomite in central Switzerland. Environ. Microbiol. 2003, 5, 618-627. [CrossRef] [PubMed]

61. Casamatta, D.A.; Johansen, J.R.; Vis, M.L.; Broadwater, S.T. Molecular and morphological characterization of ten polar and near-polar strains within the oscillatoriales (cyanobacteria). J. Phycol. 2005, 41, 421-438. [CrossRef]

62. Monteith, J.; Unsworth, M. Principles of Environmental Physics: Plants, Animals, and the Atmosphere; Academic Press: Cambridge, MA, USA, 2013; ISBN 0-12-386993-5.

63. Dahmani, J.; Benharbit, M.; Fassar, M.; Hajila, R.; Zidane, L.; Magri, N.; Belahbib, N. Vascular plants census linked to the biodeterioration process of the Portuguese city of Mazagan in El Jadida, Morocco. J. King Saud Univ. Sci. 2020, 32, 682-689. [CrossRef]

64. Almeida, M.; Mouga, T.; Barracosa, P. The weathering ability of higher plants. The case of Ailanthus altissima (Miller) Swingle. Int. Biodet. Biodeg. 1994, 33, 333-343. [CrossRef]

65. Celesti-Grapow, L.; Blasi, C. The Role of Alien and Native Weeds in the Deterioration of Archaeological Remains in Italy. Weed Technol. 2004, 18, 1508-1513.

66. Trotta, G.; Savo, V.; Cicinelli, E.; Carboni, M.; Caneva, G. Colonization and damages of Ailanthus altissima (Mill.) Swingle on archaeological structures: Evidence from the Aurelian Walls in Rome (Italy). Int. Biodeterior. Biodegrad. 2020, 153, 105054. [CrossRef]

67. Korkanç, M.; Savran, A. Impact of the surface roughness of stones used in historical buildings on biodeterioration. Constr. Build. Mater. 2015, 80, 279-294. [CrossRef]

68. Warscheid, T.; Braams, J. Biodeterioration of stone: A review. Int. Biodeterior. Biodegrad. 2000, 46, 343-368. [CrossRef]

69. Franzoni, E. State-of-the-art on methods for reducing rising damp in masonry. J. Cult. Herit. 2018, 31, S3-S9. [CrossRef]

70. Thomson, M. Characterisation of Old Mortars with Respect to their Repair-Final Report of RILEM TC 167-COM; Rilem Publications: Marne-la-Vallée, France, 2005; pp. 77-106.

71. Pfendler, S.; Karimi, B.; Maron, P.-A.; Ciadamidaro, L.; Valot, B.; Bousta, F.; Alaoui-Sosse, L.; Alaoui-Sosse, B.; Aleya, L. Biofilm biodiversity in French and Swiss show caves using the metabarcoding approach: First data. Sci. Total. Environ. 2018, 615, 1207-1217. [CrossRef] [PubMed]

72. Caneva, G.; Fidanza, M.R.; Tonon, C.; Favero-Longo, S.E. Biodeterioration Patterns and Their Interpretation for Potential Applications to Stone Conservation: A Hypothesis from Allelopathic Inhibitory Effects of Lichens on the Caestia Pyramid (Rome). Sustainability 2020, 12, 1132. [CrossRef]

73. Cennamo, P.; Montuori, N.; Trojsi, G.; Fatigati, G.; Moretti, A. Biofilms in churches built in grottoes. Sci. Total. Environ. 2016, 543, 727-738. [CrossRef] [PubMed]

74. Otlewska, A.; Adamiak, J.; Gutarowska, B. Application of molecular techniques for the assessment of microorganism diversity on cultural heritage objects. Acta Biochim. Pol. 2014, 61, 217-225. [CrossRef] [PubMed]

75. Schabereiter-Gurtner, C.; Pinar, G.; Lubitz, W.; Rölleke, S. An advanced molecular strategy to identify bacterial communities on art objects. J. Microbiol. Methods 2001, 45, 77-87. [CrossRef]

76. Saarela, M.; Alakomi, H.-L.; Suihko, M.-L.; Maunuksela, L.; Raaska, L.; Mattila-Sandholm, T. Heterotrophic microorganisms in air and biofilm samples from Roman catacombs, with special emphasis on actinobacteria and fungi. Int. Biodeterior. Biodegrad. 2004, 54, 27-37. [CrossRef]

77. Bastian, F.; Alabouvette, C.; Saiz-Jimenez, C. The impact of arthropods on fungal community structure in Lascaux Cave. J. Appl. Microbiol. 2009, 106, 1456-1462. [CrossRef] [PubMed]

78. Bastian, F.; Jurado, V.; Novakova, A.; Alabouvette, C.; Saiz-Jimenez, C. The microbiology of Lascaux Cave. Microbiology 2010, 156, 644-652. [CrossRef]

79. Kolařík, M.; Kubátová, A.; Hulcr, J.; Pažoutová, S. Geosmithia Fungi are Highly Diverse and Consistent Bark Beetle Associates: Evidence from their Community Structure in Temperate Europe. Microb. Ecol. 2008, 55, 65-80. [CrossRef]

80. Ienco, A.; Bernardini, V.; Scalercio, S.; Turco, R.; Corona, P. Updating the mapping of cork oak forests in Calabria (Italy). For. J. Silvic. For. Ecol. 2020, 17, 30-32. [CrossRef] 
81. Popović, S.; Simić, G.S.; Stupar, M.; Unkovic, N.; Predojevic, D.; Jovanovic, J.; Grbić, M.L. Cyanobacteria, algae and microfungi present in biofilm from Božana Cave (Serbia). Int. J. Speleol. 2015, 44, 141-149. [CrossRef]

82. Castlebury, L.A.; Rossman, A.Y.; Sung, G.-H.; Hyten, A.S.; Spatafora, J.W. Multigene phylogeny reveals new lineage for Stachybotrys chartarum, the indoor air fungus. Mycol. Res. 2004, 108, 864-872. [CrossRef]

83. Pandey, V. Rock-Dwelling Cyanobacteria: Survival Strategies and Biodeterioration of Monuments. Int. J. Curr. Microbiol. Appl. Sci. 2013, 2, 519-524.

84. Crispim, C.A.; Gaylarde, P.M.; Gaylarde, C.C. Algal and Cyanobacterial Biofilms on Calcareous Historic Buildings. Curr. Microbiol. 2003, 46, 79-82. [CrossRef]

85. Hauer, T. Phototrophic biofilms on the interior walls of concrete Iterson-type cooling towers. Environ. Boil. Fishes 2010, 22, 733-736. [CrossRef]

86. Ortega-Calvo, J.-J.; Hernandez-Marine, M.; Saiz-Jimenez, C. Biodeterioration of building materials by cyanobacteria and algae. Int. Biodeterior. 1991, 28, 165-185. [CrossRef]

87. Zammit, G.; Billi, D.; Shubert, E.; Kaštovský, J.; Albertano, P. The biodiversity of subaerophytic phototrophic biofilms from Maltese hypogea. Fottea 2011, 11, 187-201. [CrossRef]

88. Cuzman, O.A.; Ventura, S.; Sili, C.; Mascalchi, C.; Turchetti, T.; D’Acqui, L.P.; Tiano, P. Biodiversity of Phototrophic Biofilms Dwelling on Monumental Fountains. Microb. Ecol. 2010, 60, 81-95. [CrossRef]

89. Miller, A.Z.; Laiz, L.; Dionísio, A.; Macedo, M.F.; Saiz-Jimenez, C. Growth of phototrophic biofilms from limestone monuments under laboratory conditions. Int. Biodeterior. Biodegrad. 2009, 63, 860-867. [CrossRef]

90. Komárek, J. Phenotype Diversity of the Cyanobacterial Genus Leptolyngbya in the Maritime Antarctic. Pol. Polar Res. 2006, 28, 211-231.

91. Macedo, M.F.; Miller, A.Z.; Dionísio, A.; Saiz-Jimenez, C. Biodiversity of cyanobacteria and green algae on monuments in the Mediterranean Basin: An overview. Microbiol. Read. Engl. 2009, 155, 3476-3490. [CrossRef]

92. Silva, M.; Naik, T. Biodeterioration of Concrete Structures in Coastal Zone. In Proceedings of the Third International Conference on Sustainable Construction Materials and Technologies, Kyoto, Japan, 18-21 August 2013.

93. Chao, A.; Shen, T.-J. Nonparametric estimation of Shannon's index of diversity when there are unseen species in sample. Environ. Ecol. Stat. 2003, 10, 429-443. [CrossRef]

94. Conti, F.; Abbate, G.; Alessandrini, A.; Blasi, C. An Annotated Checklist of the Italian Vascular Flora; Springer: Berlin, Germany, 2005; ISBN 88-7621-458-5.

95. Rojas, T.I.; Aira, M.J.; Batista, A.; Cruz, I.L.; González, S. Fungal biodeterioration in historic buildings of Havana (Cuba). Grana 2012, 51, 44-51. [CrossRef]

96. Grbic, M.L.; Simic, G.S.; Stupar, M.; Jelikic, A.; Sabovljevic, M.; Dordevic, M.; Vukojevic, J. Biodiversity's Hidden Treasure:Biodeteriorated Archaeological Tombstones of Serbia. Curr. Sci. 2017, 112, 304. [CrossRef] 